\title{
THE COMPETITIVENESS OF PRONOJIWO SNAKE FRUIT
}

\author{
Soetriono ${ }^{1, *}$, Djoko Soejono ${ }^{1}$, Ariq Dewi Maharani ${ }^{1}$ and Dimas Bastara Zahrosa ${ }^{1}$ \\ ${ }^{1}$ Department of Agribusiness, Faculty of Agriculture, University of Jember, Jember, Indonesia
}

\begin{abstract}
This study aims to analyze the comparative and competitive advantages of Pronojiwo snake fruit and his farming development strategies to be competitive in the international market. Location determination is done intentionally in Pronojiwo Village, Lumajang Regency. The data used includes primary data and secondary data. Data analysis using PAM (Policy Analysis Matrix) and SWOT (Strength, Weakness, Opportunity, Threat). The results showed that the DRC value of Pronojiwo snake fruit farming was 0.20 or DRC $<1$ and the PCR value was 0.13 or PCR $<1$. Both criteria indicate that $\mathrm{DRC}$ and $\mathrm{PCR}<1$ so that it can be said that Pronojiwo snake fruit farming has comparative and competitive advantages or strong competitiveness. Smaller DRC values than PCR (DRC $<$ PCR) values indicate divergence due to government policies that still do not support the development of them. The position of the development of Pronojiwo snake fruit is in the Gray Area position. The strategy to develop Pronojiwo snake fruit which must be done is to maintain product quality, an effective means of transportation is needed and is supported by the use of appropriate technology so that products can compete in a healthy manner with products from other countries.
\end{abstract}

\section{INTRODUCTION}

Snake fruit (Salacca edulis R.) is a tropical fruit in Indonesia which is spread throughout the most regions of Indonesia. In the period of 2010-2014, snake fruit is one of the strategic horticultural commodities that has been designated as a national superior commodity along with commodities such as chili, shallots, potatoes, oranges, mangoes, mangosteen, bananas, durians, rhizomes, orchids and chrysanthemums [1]

In East Java there are salak pondoh varieties that have the potential to be exported overseas. In 2014, salak fruit production in East Java was 66,802 tons and salak fruit production in 2015 was 105,020 tons. The most known salak in East Java Province is Pronojiwo salak. Pronojiwo's snakefruit cultivation is located in Pronojiwo District, Lumajang Regency. The largest fruit production in Pronojiwo District in 2015 was the production of zalacca by 386,951 quintals. In 2015 , salak production increased sharply from 2014 which only reached 1,179 quintals [2].

This Pronojiwo Snake fruit variety comes from salacca seedlings taken from Pondoh snake fruit in Sleman Regency, Special Region of Yogyakarta. The seeds were brought to Lumajang Regency and then planted in Pronojiwo Subdistrict. The snake fruit can develop well in terms of taste and thickness of the flesh. The advantages of Pronojiwo snake fruit are from its sweeter taste, thick and large fruit flesh, and high water content.

Pronojiwo snake fruit is a horticultural product that is recognized in Indonesia and has a GAP (Global Agricultural Practices) certificate. The GAP certificate is a certification with an agricultural production process that uses advanced technology that is so eco-friendly and sustainable that harvested products are safe for consumption; workers' welfare is also considered, and its farming provides economic benefits to farmers. This certification is the main requirement so that national fruit products can compete among the onslaught of ASEAN products [3]. The demand for Pronojiwo snake fruit is increasing. Besides being in demand by the local market, Pronojiwo snake fruit is in great demand in Malaysia and Singapore. For this reason, it is necessary to examine the analysis of the comparative and competitive advantages of Pronojiwo snake fruit and its farming development strategies to be competitive in the international market.

\section{RESEARCH METHOD}

The study was conducted in Lumajang Regency, the center of Pronojiwo snake fruit production. The data collected were the primary data and secondary data. Primary data was collected by interviewing snake fruit farmers and key informants.

The sample was taken using purposive sampling and incidental sampling. According to [4], purposive Sampling is a deliberate sampling in which participants are selected according to the needs of the study. Incidental Sampling is a technique of determining samples based on coincidence, that is, anyone who accidentally or incidentally meets with a researcher can be used as a sample, as long as the person meets the criteria as a data source.

To answer the comparative and competitive advantages of Pronojiwo snake fruit commodity, the PAM matrix was used with the following formulations [5]. 
Table 1. Policy Analysis Matrix

\begin{tabular}{|c|c|c|c|c|}
\hline \multirow[b]{2}{*}{ Items } & \multicolumn{3}{|c|}{ Costs } & \multirow[b]{2}{*}{ Surplus } \\
\hline & Tradeble & $\begin{array}{c}\text { Input } \\
\text { Tradeable }\end{array}$ & $\begin{array}{l}\text { Input non } \\
\text { Tradeable }\end{array}$ & \\
\hline $\begin{array}{l}\text { Privat } \\
\text { Price }\end{array}$ & A & $\mathrm{B}$ & $\mathrm{C}$ & $\mathrm{D}$ \\
\hline $\begin{array}{l}\text { Social } \\
\text { Price }\end{array}$ & $\mathrm{E}$ & $\mathrm{F}$ & G & $\mathrm{H}$ \\
\hline Divergensi & I & $\mathrm{J}$ & $\mathrm{K}$ & $\mathrm{L}$ \\
\hline
\end{tabular}

Note :

A : Private Revenue

B : Private cost of Tradable Inputs

C : Private Cost of Non-Tradable Inputs

D : Private Profit

E : Social Revenue

F : Social Cost of Tradable Inputs

$\mathrm{G}$ : Social Cost of Non Tradable Inputs

$\mathrm{H}$ : Social Profits

I : Output Transfers

J : Input Tradable Transfers

$\mathrm{K}$ : Input Non tradable Transfers

L : Net Transfers

To find out comparative and competitive advantages based on the PAM Pronojiwo snake fruit matrix, the formulation is as follows:

1. The comparative advantage of using Domestic Resource Cost Ratios (DRC)

Social Cost of Non Tradable Inputs (G)

$\mathrm{DRC}=$

Note:

Social Revenue (E) - Social Cost of Tradable Inputs (F)

$\mathrm{G}=$ Costs of fertilizer + seedling costs + cost of plastic bags at the social price of Pronojiwo snake fruit (IDR/ha)

$\mathrm{E}=$ Production of Pronojiwo snake fruit $(\mathrm{Kg} / \mathrm{ha}) \mathrm{x}$ social price of Pronojiwo snake fruit (IDR/Ha)

$\mathrm{F}=$ Costs of urea fertilizer at social prices (IDR/Ha)

Decision criteria:

a. DRC $<1$ means that economic activity is economically efficient in the use of domestic resources or that economic activity has a comparative advantage so that domestic fulfillment is more profitable with an increase in domestic production

b. DRC $>1$ means that economic activity is not economically efficient in the use of domestic resources or that economic activity causes comparative losses.

2. Competitive advantage using Private Costs Ratio (PCR)

Private Cost of Non tradable Inputs (C)

$\mathrm{PCR}=$ Note:

Private Revenue (A)- Private Cost of Tradable Input (B)

$\mathrm{B}=$ Costs of organic fertilizer + seedling cost + cost of plastic bags at the private prices of Pronojiwo snake fruit (IDR/Ha)
$\mathrm{A}=$ Production of Pronojiwo snake fruit $(\mathrm{Kg} / \mathrm{ha}) \mathrm{x}$ private price of Pronojiwo snake fruit (IDR /Ha)

$\mathrm{C}=$ Costs of urea fertilizer at private prices (IDR/Ha)

Criteria for decision making:

a. PCR $<1$ means that the economic activity of Pronojiwo snake fruit has a competitive advantage and the commodity of Pronojiwo snake fruit can compete both in the domestic and international markets with assumptions on marketing and government policy

b. PCR $>1$ means that the economic activity of Pronojiwo snake fruit does not have any competitive advantage and causes Pronojiwo snake fruit commodity to not compete in both domestic and international markets

c. $\mathrm{PCR}=1$ means that the economic activity of Pronojiwo snake fruit provides a normal profit or the activity is at a break-even point.

The second problem regarding the development strategy of Pronojiwo snake fruit farming, a SWOT analysis was used (Strengths, Weaknesses, Opportunities, Threats). According to [6], the first stage of SWOT analysis in developing strategies is arranging the analysis of internal factors evaluation (EFI) which consists of strengths and weaknesses as well as external factor evaluation (EFE) which consists of opportunities and threats.

Based on the calculation of internal and external condition factor values on Pronojiwo snake fruit rfarming, it can be compiled into a competitive position matrix relative to the Pronojiwo snake fruit farming shown in the diagram as follows:

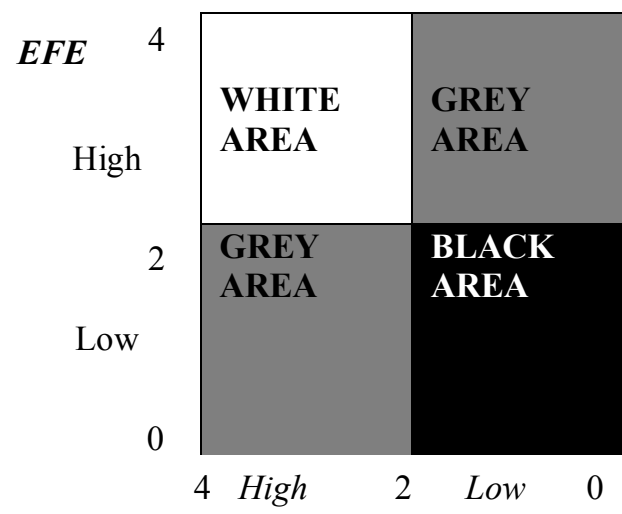

EFI

Fig 1. Relative Competitive Position Matrix

The decision criteria are as follows:

a. If farming is in the White Area, then farming has a prospective market opportunity and has the competence to do it.

b. If farming is in the Grey Area, then farming has a prospective market opportunity but does not have the competence to do it.

c. If farming is in the Grey Area, then farming is strong enough and has the competence to do it, but the market opportunity is very threatening.

If farming is in the Black Area (Weak-Threatened Area), then farming has no market opportunity and does not 
have the competence to do it.33 RESULTS AND DISCUSSIONS

\subsection{Comparative Advantage of Pronojiwo snake fruit}

The cost analysis of domestic resources based on social prices is used to detect comparative advantages in Pronojiwo snake fruit farming. The comparative advantage of Pronojiwo snake fruit farming in the PAM matrix table can be seen from the coefficient of DRC (Domestic Resources Cost). If the DRC value is smaller than one $(\mathrm{DRC}<1)$, meaning that it has a comparative advantage. The level of economic efficiency in the comparative advantages of Pronojiwo snake fruit commodity is indicated by the number of DRC (Domestic Resource Cost). The DRC value is smaller than one, meaning that producing Pronojiwo snake fruit is efficient in terms of domestic resource use. In other words, economically producing Pronojiwo snake fruit in the country is more efficient and profitable than importing. Conversely, if the DRC value is greater than one, it means producing Pronojiwo snake fruit is not efficient in terms of domestic resource use and regionality occurs comparatively. The results of the calculation using the PAM matrix are as follows.

Tabel 2. PAM Pronojiwo Snake Fruit

\begin{tabular}{lcccc}
\hline \multirow{2}{*}{ Description } & \multicolumn{2}{c}{ Tradables } & \multicolumn{2}{c}{$\begin{array}{c}\text { Total } \\
\text { Domestic Factors }\end{array}$} \\
\cline { 2 - 3 } & Output & Inputs & 10.078 .595 & 68.595 .355 \\
Private prices & 79.426 .200 & 752.250 & 18.307 .873 & 73.062 .870 \\
Social prices & 132.108 .666 & 40.737 .924 & -8.229 .277 & -4.467 .515 \\
Policy Transfers & -52.682 .466 & -39.985 .674 & & \\
\hline
\end{tabular}

$\mathrm{DRC}=0,20 ; \mathrm{PCR}=0,13$

Source: Primary data, processed in 2019

The results of the comparative advantage analysis of Pronojiwo snake fruit are seen using the PAM matrix of 0.20 or the DRC value is less than $1(\mathrm{DRC}<1)$. This indicates that Pronojiwo snake fruit farming is economically efficient in using domestic resources because to produce one-unit foreign exchange only a domestic factor cost of around 0.80 units is needed. This DRC value also shows the cost of producing Pronojiwo snake fruit for 20 percent of the import cost. If the fulfillment of Pronojiwo snake fruit demand is made from domestic production, it will be able to save foreign exchange by 80 percent of the required import costs. Based on the results of the analysis, Pronojiwo snake fruit farming has a comparative advantage.

Another proof is that Pronojiwo snake fruit farming has a comparative advantage, indicated by a profit value greater than zero (positive value), where the profit is derived from the difference between social income and domestic factor cost. Income and cost for analysis of comparative advantage are calculated based on social prices. The value of Pronojiwo snake fruit social profit is Rp. 73,062,869.56.The calculation of comparative advantage shows two cost structures used in its farming, namely tradeable input costs and domestic factor costs.

\subsection{Competitive Advantage of Pronojiwo snake fruit}

The analysis of domestic resource cost based on private prices is used to detect competitive advantage in Pronojiwo snake fruit farming where competitive advantage is the actual standard to measure competitiveness in prevailing market conditions without questioning the presence or absence of market distortions. The competitive advantage of Pronojiwo snake fruit farming on the PAM matrix can be figured out from the coefficient of PCR (Private Cost Ratio), where, if the PCR value is smaller than one, then it has a competitive advantage. The results of the analysis of competitive advantage can be seen using the PAM matrix. PCR value is the ratio between domestic factor costs and value-added output from domestic factor costs traded at prices at the farmer level. The results of the analysis prove that the value of competitive advantage was obtained at 0,13 (lower than 1). These results prove that Pronojiwo snake fruit has a competitive advantage. The value of competitive advantage of 0,13 means that to produce one unit value-added output on private prices, only requires 87 percent of domestic resources. This PCR value indicates that the amount of costs that must be sacrificed due to the use of resources at market prices is lower than the profits obtained by producers for each one-unit currency (rupiah). The smaller the value of the PCR, the more Pronojiwo snake fruit will be privately efficient and the greater the competitive advantage.

Another evidence that Pronojiwo snake fruit farming can still be run, is indicated by the value of profit (financial profit) which is greater than zero (positive value), where the profit is derived from the difference between private income and private cost. Private incomes and costs for the analysis of competitive advantage are calculated based on the actual prices received and paid by farmers. The private profit value of Pronojiwo snake farming is positive, which is $\mathrm{Rp}$. $68,595,354.92$ per hectare. The results of the calculation of competitive advantage show two cost structures used in Pronojiwo snake fruit farming, namely tradeable input costs and domestic factor costs. Domestic factors represent the total costs incurred by Pronojiwo snake fruit farmers which consist of labor costs, non-tradable inputs (seeds and manure) and working capital. The 
labors employed by farmers are mostly from outside the family. The farmers generally use their capital in the cultivation of Pronojiwo snake fruit plants, although some farmers take out loans with working capital of 12 percent where the monthly return on capital is 1 percent for BNI [7].

\subsection{Development Strategy of Pronojiwo Snake Fruit}

To find out and formulate the design form of the strategy for developing Pronojiwo snake fruit farming, identification of internal and external environmental conditions was carried out. The factors of internal and external environmental conditions can be explained in Table 3.

Internal strategy factor analysis consists of strengths (strengths) and weaknesses (weaknesses). Strength can be explained as a resource advantage on Pronojiwo snake fruit farming and its progress in determining changes in export operations strategies. The Strength variables in farming are five variables consisting of S1 to S5. Weaknesses can be explained as weaknesses in farming that illustrate limited resource and farming capabilities that seriously prevent effective performance in developing export operation strategies. The Weakness variables in Pronojiwo snake fruit farming are three variables consisting of W1 to W4.

External strategy factor analysis consists of opportunities and threats. Opportunities can be explained as situations outside farming that are beneficial in developing operating strategies in the farming environment. Opportunity variables in farming have five variables consisting of $\mathrm{O} 1$ to $\mathrm{O} 4$. Threats can be explained as unfavorable situations that create threats and obstacles that come from the outside of the farming environment. The threat variables in farming have four variables consisting of $\mathrm{T} 1$ to $\mathrm{T} 4$.

Table 3. Strengths, Weaknesses, Opportunities, and Threats of Pronojiwo Snake Fruit Farming

\begin{tabular}{|c|c|c|c|}
\hline Strengths (S) & Weaknesses (W) & Opportunities (O) & Threats (T) \\
\hline $\begin{array}{l}\text { 1. Availability of } \\
\text { commodities }\end{array}$ & $\begin{array}{l}\text { 1. Storage and packing } \\
\text { technology }\end{array}$ & $\begin{array}{l}\text { 1. Geographical situation } \\
\text { (climate) }\end{array}$ & $\begin{array}{l}\text { 1. Transportation } \\
\text { facilities }\end{array}$ \\
\hline 2. Product quality & 2. Price of expensive & Consumer trust & 2. Commodity damage \\
\hline $\begin{array}{l}\text { 3. Selling prices of } \\
\text { products }\end{array}$ & $\begin{array}{ll} & \text { technology } \\
\text { 3. } & \text { Farm location (market) }\end{array}$ & $\begin{array}{l}\text { 3. Farmer groups } \\
\text { 4. Training from PPL }\end{array}$ & $\begin{array}{l}\text { 3. Competition in } \\
\text { foreign markets }\end{array}$ \\
\hline $\begin{array}{l}\text { 4. Location of commodity } \\
\text { cultivation } \\
\text { 5. Capital }\end{array}$ & $\begin{array}{l}\text { 4. There is no market } \\
\text { guarantee }\end{array}$ & & 4. Government Policy \\
\hline
\end{tabular}

The results of the calculation of the internal and external condition factor values on Pronojiwo snake fruit farming through a SWOT analysis, the prospect of Pronojiwo snake fruit farming can be compiled into the relative competitive position matrix in Figure.

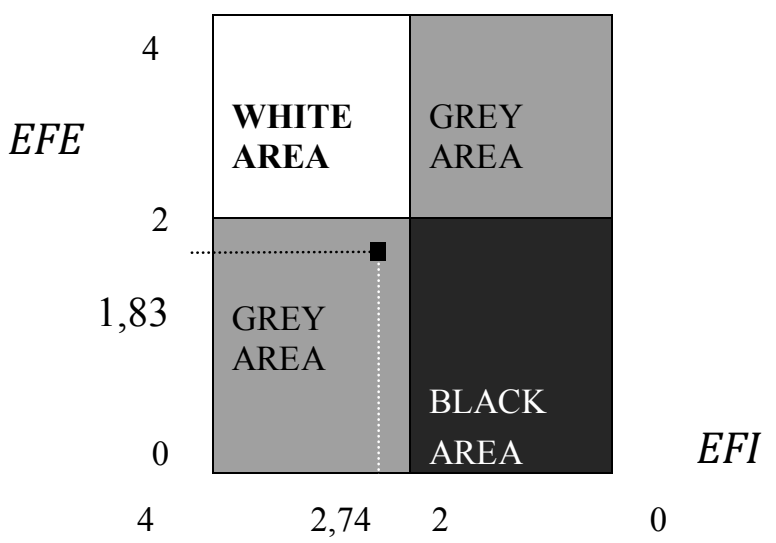

Fig 1. Relative Competitive Position Matrix Diagram of Pronojiwo Snake Fruit

Based on the results of the analysis, internal strategy factors obtained EFI value of 2.74 and external strategy factors obtained EFE value of 1.83 . This value places the position of Pronojiwo snake fruit farming in the Grey Area position as shown in the picture above, which means that the farm is strong enough and has the competence to do it, but the market opportunity is very threatening. The Grey Area results are influenced by the small value of external factors, where many external factors discussed by the researcher were on the aspect of product damage which becomes a threat to Pronojiwo snake fruit farmers because they can reduce the quality of Pronojiwo snake fruit.

Regarding that issue, therefore, farmers should minimize the threats by optimizing the strengths they have. The strengths are the availability of commodities, the price of commodities per kilogram, the location of commodity cultivation, capital and the quality of Pronojiwo snake fruit, while the threats posed are transportation facilities, product damage, foreign market competition, and government policies.

The appropriate strategy for Pronojiwo snake fruit farming in developing his business is using strategies to take advantage of long-term opportunities. The External Internal Matrix of Pronojiwo snake fruit is as follows. 
TOTAL SCORE EFE

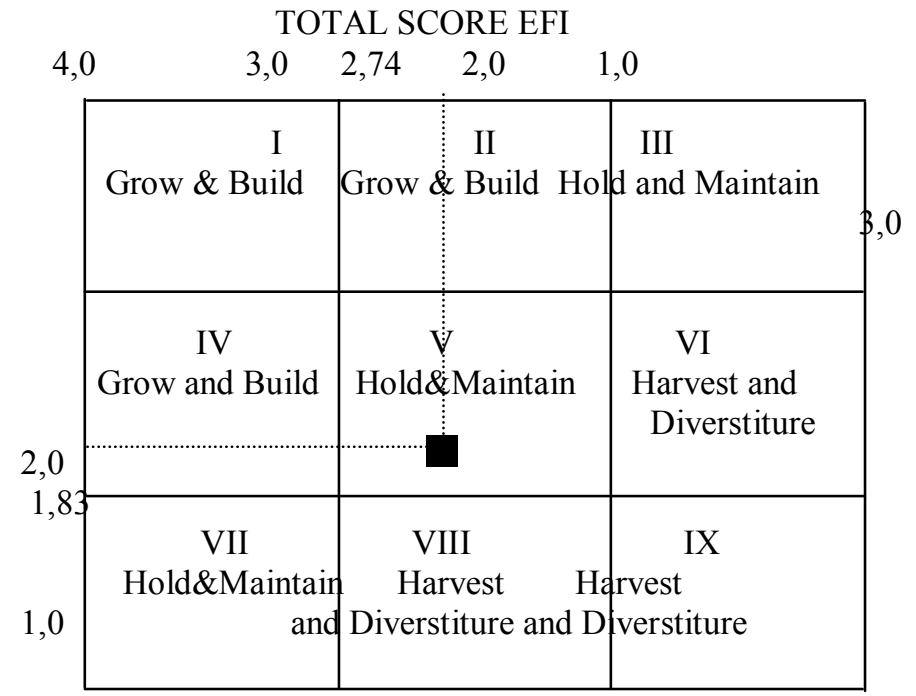

Fig 2. The External Internal Matrix of Pronojiwo Snake Fruit

The picture above shows the value of internal strategy factors obtained by the results of 2.74 and external strategy factors obtained by the results of 1.83 . The growth of the position of Pronojiwo snake fruit farming is in area VIII (growth). The growth stage describes that the farmers must increase the value of production and sales by utilizing internal power and minimizing the external threats. In the end, the farmers must take advantage of the strengths and minimize the external threats of farming to gain opportunities through exports. Therefore, the development strategy of Pronojiwo snake fruit farming can be obtained.

The sustainability of Pronojiwo snake fruit in the future is very much needed in the implementation of business strategies. The strategy that can be applied in Pronojiwo snake fruit farming based on farming estimation from internal and external factors that influence the activities of Pronojiwo snake fruit farming can be established of four main strategies between S-O, W-O, S-T, and W-T through the SWOT matrix.

\section{S-O STRATEGY}

1. Increase production volume by utilizing information from PPL.

2. Maintaining product quality while still implementing SPO in the process of modification

\section{S-T STRATEGY}

1. Existing strengths (price, quality, capital) must be improved and utilized properly to attract markets and reduce unfair competition markets and can further improve their farming

Fig 3. SWOT Matrix of Pronojiwo Snake Fruit

Source: Primary data, processed in 2019

\section{CONCLUSIONS}

1. Pronojiwo Snake Fruit has comparative and competitive advantages. The value of Pronojiwo snake fruit comparative advantage or DRC value of 0.20 (DRC $<1$ ) with the value of Pronojiwo snake fruit social profit of Rp. 73,062,869.56. The value of competitive advantage or PCR obtained at 0.13 (PCR $<1)$ with the positive value of private profit which equals to Rp. 68,595,354.92 per hectare.Pronojiwo snake fruits.

2. The development strategy of Pronojiwo snake fruit is in the Grey Area position, with the marketing strategy that must be done is to maximize S-T strategy of maintaining product quality, an effective means of transportation is needed and supported by the use of

\section{W-O STRATEGY}

1. Maximizing information from PPL so that farmers can market the products and obtain a fixed market

2. Facilitating farmers with private companies in marketing products

\section{W-T STRATEGY}

1. To overcome existing problems, the government must be able to provide storage technology facilities and packing for exported commodities appropriate technology, and therefore the products can compete healthily with products from other countries.

\section{Refferensi}

[1] Directorate General of Horticulture. Pedoman Sistem Jaminan Mutu Salak Pondoh Kabupaten Lumajang. Jakarta (2015).

[2] BPS. Nilai Ekspor Impor Jawa Timur (2016).

[3] Heriyanto, Bambang. Pisang dan Salak Lumajang Bersertifikat Internasional (2016).

[4] Nazir. Metode Penelitian. Ghalia Indonesia. 2003.

[5] Pearson, S, Carl Gotsch dan Sjaiful Bahri. Aplikasi Policy Analysis Matrix pada Pertanian Indonesia. Yayasan Obor Indonesia (2005). 
[6] Rangkuti, F. Teknik Membedah Kasus Bisnis Analisis SWOT Cara Perhitungan Bobot, Rating dan OCAI. PT. Gramedia Pustaka Utama (2016).

[7] Kementerian Keuangan Republik Indonesia. APBN 2016 (2016). 